\title{
Molecular Identification and Isolation of Antimicrobial, Phytochemical, Antioxidant Properties of Different Solvent Extracts from Wild Mushrooms
}

PGS Manjusha*

Department of Microbiology, Researcher, Shoolini University of Biotechnology and Management Sciences, Solan, Himachal Pradesh-173212, India

DOI: $10.36348 /$ sjpm.2020.v05i02.011

| Received: 14.02.2020 | Accepted: 21.02.2020 | Published: 23.02.2020

*Corresponding author: PGS Manjusha

\section{Abstract}

The main objective of the present research work was to identify the unknown wild mushrooms based on morphological characteristics and DNA based sequencing by using universal primers ITS 1 and ITS 4 which were collected from Andhra Pradesh and Telangana. To test the potential of various extracts of mushrooms by using three different solvents (Methanol, Hot Water and Hexane). To elucidate antimicrobial properties, qualitative and quantitative estimation of phytochemical properties and antioxidant activity was determined by DPPH free radical scavenging activity. Then, $\mathrm{IC}_{50}$ values were determined. The four isolates were identified on the basis of morphological and molecular characterization was identified as Trametes versicolor, Daedaleopsis confragosa, Schizophyllum communae and Tyromyces chioneus. Three different solvents had been shown good antimicrobial activity against all pathogenic microorganisms. The hot water extract of $T$. versicolor exhibited more amount of phenol content $(11.13 \pm 0.081)$ and ascorbic acid content (9.62 \pm 0.086$)$. Methanol extract of $S$. communae showed high amount of flavonoids content (12.58 \pm 0.138$)$. Methanol extract of $T$. chioneus exhibited more amount of $\beta$-carotene $(3.54 \pm 0.010)$ and hot water extract of $D$. confragosa exhibited more amount of lycopene content $(2.29 \pm 0.012)$. The DPPH free radical scavenging activity and $\mathrm{IC}_{50}$ values was much more exhibited by methanol extracts then followed by hot water extracts and hexane extracts of wild mushrooms they all have exhibited stronger antioxidant activity between $(40-50 \mu \mathrm{g} / \mathrm{ml})$. This comprehensive analysis demonstrates that these mushrooms having a viable source of natural antioxidants that can utilized for functional foods, nutraceutical's applications with beneficial biological activities and implementation of new drug discovery.

Keywords: Antimicrobial, Antioxidant, DNA isolation, Mushrooms and Phytochemical.

Copyright @ 2020: This is an open-access article distributed under the terms of the Creative Commons Attribution license which permits unrestricted use, distribution, and reproduction in any medium for non-commercial use (NonCommercial, or CC-BY-NC) provided the original author and sources are credited.

\section{Abbrevations \\ DNA - Deoxyribonucleic acid \\ DMSO - Di methyoxy sulfoxide \\ DPPH - 1, 1-diphenyl -2-picrylhydrazyl \\ MEA - Malt Extract Agar \\ MHA - Muller Hinton Agar \\ MHB - Muller Hinton Broth \\ PCR - Polymerase Chain Reaction}

\section{Highlights of the Paper}

- The four isolates of Wild mushrooms are Trametes versicolor, Daedaleopsis confragosa, Schizophyllum communae and Tyromyces chioneus has shown good antimicrobial activity against pathogenic microorganisms.
- Also, they have exhibited good potential of antioxidant properties.

- Molecular identification is done for these species, therefore DNA is extracted by liquid nitrogen method and sequences are submitted to Gene Bank further they provided with accession numbers and Phylogenetic Tree was constructed.

- Hence, comprehensive analysis demonstrates that these mushrooms having a viable source of natural antioxidants that can utilized as functional foods, nutraceutical's applications with beneficial biological activities and implementation of new drug discovery, if further investigation is processed. 


\section{INTRODUCTION}

The world of fungi is large and diverse in ecosystem. Wild mushrooms are important sources of natural bioactive compounds and are antioxidant potential. Therefore, mushroom is a type of a fleshy fruiting body of some fungi which are arising from a group of mycelia buried in substratum [1]. Most of them are basidiomycetes and are gilled. Based on their spores, they are called as a basidiospores [2]. Wild mushrooms are either epigeous or hypogeous heterotrophic organisms that belong to the Basidiomycota and Ascomycota divisions [3]. Many of the wild mushroom species are becoming important parts of the livelihoods of humans now days in different parts of the world [4], and being collected as valuable product of Non -Timber Forest Products (NTFPs) [5]. Now a day's microorganisms are becoming serious threat to mankind by becoming more drug resistance. Due to long term indiscriminate use of drugs against antimicrobial agents they are becoming more resistance which results in acquisition of mutation in the genome and genes of disease-causing microorganisms that assist their survival [6]. Therefore, it is not possible to prevent the microbial evolution, but it is important to choose the most appropriate reliable antibiotics and use them properly to reduce the development of drug resistant strains [7]. As we all know wild mushrooms are a good source of nutrition and having wide range of medicinal values [8].

\section{MATERIALS AND METHODS}

\section{Collection, isolation and morphological characteristics of wild mushrooms:}

Wild mushroom samples are collected from Andhra Pradesh and Telangana forest area and was labelled as sample no. 1/18, 2/18, 3/18, 4/18. The samples were kept in sterile plastic bag. Brought it to laboratory and washed thoroughly with sterile distilled water and $0.001 \%$ mercuric chloride and with the help of sterile blade it was brake into length wise of the tissue. The bits aseptically transferred onto a MEA. The four samples replicates were made and the plates incubated at $25^{\circ} \mathrm{C}$ temperature for 7 days. Sub-culture was done from mother inoculum plates to pure MEA plates to obtain the pure cultures. Therefore, general characters and microscopic features were recorded.

\section{Maintenance of culture of test organisms}

Five bacterial strains were taken namely Klebsiella pneumoniae (MTCC109), Salmonella typhi (MTCC10248), Staphylococcus aureus (MTCC737), Escherichia coli (MTCC739) and Pseudomonas aeruginosa (MTCC741) obtained from Microbial Type Culture Collection (MTCC) IMTECH, Chandigarh (INDIA) and stored at $4{ }^{\circ} \mathrm{C}$ in refrigerator and sub cultured at regular intervals of $48 \mathrm{~h}$ until use. One fungal strain was taken namely Candida albicans (80CC90028) strain procured from yeast laboratory of Shoolini University.

\section{Preparation of different extracts Methanol and Hexane extracts}

Freeze-dried mycelial biomass (5g) was accurately weighed into a $100 \mathrm{ml}$ sterilin and shaken overnight (18 - 24 hours) with $50 \mathrm{ml}$ of methanol at room temperature. The extract was then filtered through Whatman paper No.1. The residue was then resuspended in another $50 \mathrm{ml}$ of methanol. The process was repeated twice. The combined methanol filtrate was transferred to a pre-weighted sterilin and the solvent was evaporated by applying a constant flow of air. Residual methanol was removed by vacuum pressure at $50^{\circ} \mathrm{C}$ overnight in an oven and the dry weight recorded. Therefore, hexane extract is also prepared as same as methanol extract. In place of methanol add hexane solvent for preparation of hexane extract [9].

\section{Hot water extracts}

Dry mycelial biomass was accurately weighed and $10 \mathrm{ml}$ deionized water was added to it. The mixture was heated at $100^{\circ} \mathrm{C}$ for 20 minutes and allowed to cool for 20 minutes. After this, the filtrate was separated from the mycelial biomass by using No. 42 Whatman filter paper. The process was repeated twice. The combined filtrate was then freeze-dried and the dry weight of sample was recorded [10].

\section{Antimicrobial activity}

MHA plates with $4 \% \mathrm{NaCl}$ supplementation were prepared. Sterilized swabs were dipped in standardized bacterial suspension with inoculums size of $1.5 \mathrm{X} 108 \mathrm{cfu} / \mathrm{ml}$ prepared above and excess culture was removed by turning the swab against the side of the tube. Inoculum was spread evenly over the entire surface of MHA plates. These plates were allowed to dry for at least $15 \mathrm{~min}$ and then wells $(7 \mathrm{~mm}$ diameter) were made on petridish using sterile cork borer. About $25 \mu l$ extract was introduced into bore agar wells using sterile dropping pipette. These plates were kept inside the refrigerator at $4^{\circ} \mathrm{C}$ for 6 hours to allow proper diffusion of extracts into medium. The plates were then examined for antibacterial activities of extracts after 24 hours of incubation at $37^{\circ} \mathrm{C}$. Antibacterial activity was determined by measuring the diameter zone of inhibitions in $\mathrm{mm}$ [11].

\section{Minimal Restrictory concentration for estimating Antimicrobial activity}

Resazurin solution was prepared by dissolving $270 \mathrm{mg}$ of resazurin powder in $40 \mathrm{ml}$ sterile distilled water. Each well of 96-well microtiter plate was aliquoted with $50 \mu \mathrm{l}$ of MHB; 12th well (sterility control) was added with $100 \mu$ of Ciprofloxacin antibiotic as positive control. 11th well (growth control) was added with MHB with 10\% DMSO. $50 \mu \mathrm{l}$ of mycelial extract initially dissolved in $10 \%$ DMSO to the concentration of $100 \mathrm{mg} / \mathrm{ml}$ was added into the first well and a serial 2-fold dilution was performed by 
transferring $50 \mu \mathrm{l}$ of the suspension to the subsequent wells up till the 10th well; the final $50 \mu \mathrm{l}$ of the suspension was discarded. Then, of $5 \mu \mathrm{l}$ bacterial suspension was added to each well and incubated at $37^{\circ} \mathrm{C}$ for 24 hours. After 24 hours of incubation $5 \mu 1$ of resazurin was added to each well. Plates were incubated at $37^{\circ} \mathrm{C}$ for additional 1 hour. After one hour of incubation the plates were read for colour change from blue to purple/ pink. A blue coloured solution indicated the growth inhibition in the test wells, while pink to colourless solution indicated microbial growth or absence of inhibition [12].

\section{Qualitative and Quantitative analysis of bioactive compounds}

Qualitative analysis of phytochemical compounds was done for three different extracts of four wild mushrooms. For identification of alkaloids Mayer's and Wagner's test was done [13]. Molisch's and Benedict's test were performed for the identification of carbohydrates [13]. To check the presence of flavonoids alkaline reagent test was done [14]. Salkowski test was done for identification of terpenoid's (Bains and Tripathi, 2016). For identification of phenolic compounds and tannin Ferric chloride and Lead acetate test was done. Detection of glycosides was done by adding $1 \mathrm{ml}$ of glacial acetic acid and $5 \%$ of ferric chloride was added to $2 \mathrm{ml}$ of extract, presence of greenish blue colour indicates glycosides [10]. Therefore, for detection of saponins 5$10 \mathrm{ml}$ of distilled water was added to $1 \mathrm{ml}$ of extract and shaken gradually cylinder for 15 minutes, formation of foam indicates positive [15]. There by quantitative analysis of bioactive compounds was done for phenolic, flavonoid, ascorbic, $\beta$-carotene and lycopene determination.

\section{Phenolic Compound determination}

$100 \mu 1$ of all extract of mushroom samples mixed with $1.5 \mathrm{ml}$ of Folin-Ciocalteu reagent and incubated at room temperature for one minute followed by the addition of $1.5 \mathrm{ml}$ sodium carbonate $(60 \mathrm{~g} / \mathrm{l})$. The tubes would be then vortex-mixed for $15 \mathrm{~s}$ and allowed to stand for 90 minutes in dark at room temperature. Absorbance will be then measured at $725 \mathrm{~nm}$. Gallic acid used as standard curve with concentration ranges from 1 to $100 \mu \mathrm{g} / \mathrm{ml} \quad\left(\mathrm{R}^{2}=0.996\right)$ and the results expressed as $\mathrm{mg}$ gallic acid equivalent (GAE)/g. All experiments would be performed in triplicates [16].

\section{Flavonoid determination}

$250 \mu \mathrm{l}$ extract of all extract of mushroom samples mixed with $1.25 \mathrm{ml}$ of distilled water and $75 \mu \mathrm{l}$ of a $5 \% \quad \mathrm{NaNO}_{2}$ solution.150 $\mu \mathrm{l}$ of $10 \% \quad \mathrm{AlCl}_{3} \cdot \mathrm{H}_{2} \mathrm{O}$ added after $5 \mathrm{~min}$. Then $275 \mu \mathrm{l}$ of distilled water and $500 \mu \mathrm{l}$ of $1 \mathrm{M} \mathrm{NaOH}$ added to the mixture after $6 \mathrm{~min}$. The solution then mixed well and the intensity of pink colour measured at $510 \mathrm{~nm}$. The flavonoid compounds estimation would be carried out in triplicate. Quercetin used for calibration curve with concentration range of
$20-100 \mu \mathrm{g} / \mathrm{ml}\left(\mathrm{R}^{2}=0.9938\right)$. The results would be mean values \pm standard deviations and expressed as milligrams of $(+)$ quercetin equivalents (QEs) per gram of extract [17].

\section{Ascorbic acid determination}

$100 \mathrm{mg}$ of all dried extracts of mushroom samples extracted with $10 \mathrm{ml}$ of $1 \%$ metaphosphoric acid for $45 \mathrm{~min}$ at room temperature and filtered through Whatman No.4 filter paper. The filtrate $(1 \mathrm{ml})$ will be mixed with $9 \mathrm{ml}$ of 2, 6-dichloroindophenol and then absorbance will be measured within $30 \mathrm{~min}$ at 515 $\mathrm{nm}$ against a blank. Content of ascorbic acid will be calculated on the basis of the calibration curve of authentic L-ascorbic with concentration range of 2- 125 $\mu \mathrm{g} / \mathrm{ml} \quad\left(\mathrm{R}^{2}=0.9929\right)$. All the experiments would be performed in triplicates [18].

\section{$\beta$-carotene and lycopene determination}

The dried all three extracts of each mushroom samples $(100 \mathrm{mg})$ are vigorously shake with $10 \mathrm{ml}$ of acetone-hexane mixture (4:6) for $1 \mathrm{~min}$ and filtered through Whatman No.4 filter paper. The absorbance of the filtrate measured at 453, 505, 645 and $663 \mathrm{~nm}$ [19]. Content of $\beta$-carotene and lycopene were calculated by using following equations:

Lycopene $(\mathrm{mg} / 100 \mathrm{mg})=-0.0458 \mathrm{~A}_{663}+0.372 \mathrm{~A}_{505}-$ $0.0806 \mathrm{~A}_{453}$

$\beta$-carotene $(\mathrm{mg} / 100 \mathrm{mg})=0.216 \mathrm{~A}_{663}-0.304 \mathrm{~A}_{505}+0.452$ $\mathrm{A}_{453}$

\section{Scavenging activity on DPPH for antioxidant assay}

The antioxidant activity of the extracts on the stable radical DPPH was determined by the method developed by [20]. The $0.1 \mathrm{ml}$ of mushroom ethanol extract, at various concentrations was added to $3 \mathrm{ml}$ of a $0.004 \%$ methanol solution of DPPH and was allowed to stand for $30 \mathrm{~min}$ for the reaction to occur. The absorbance of the resulting solution was measured at $517 \mathrm{~nm}$ from these values the corresponding percentage of inhibitions was calculated by using the following equation:

$$
\mathrm{I} \%=\left[\left(\mathbf{A}_{\text {Blank }}-\mathbf{A}_{\text {sample }}\right) / \mathbf{A}_{\text {Blank }}\right] \times \mathbf{1 0 0},
$$

Where, $\mathrm{A}_{\text {blank }}$ is the absorbance of the control reaction (containing all reagents except the test sample) and $\mathrm{A}_{\text {sample }}$ is the absorbance of sample/standard. To get the effective concentration $\mathrm{IC}_{50}$, (defined as the concentration of antioxidant required to reducing the concentration of initial DPPH 50\%) for each extract, concentration providing $50 \%$ inhibition $\left(\mathrm{IC}_{50}\right)$ was calculated from the graph plotted $\mathrm{I} \%$ versus concentration curve. The free radical scavenging activity was measured for different concentrations of sample and compared with standard (Ascorbic acid). 
Molecular identification of wild mushroom and sequencing

Genomic DNA of wild mushrooms was isolated by manually using chemicals like liquid nitrogen, phenol, chloroform, isopropyl alcohol, ethanol, lysis buffer, SDS (Sodium dodecyl sulphate) and TE buffer. After isolation the DNA was subjected for PCR amplification. The DNA was amplified by using universal primers ITS1-(5'-TCC GTA GGT GAA CCT GCG G-3') Forward primer and ITS4-(5' TCC GCT TAT TGA TAT GC-3') Reverse primer for the region containing ITS1, ITS4 and rDNA. The reaction mixture procedure was followed by the kit (HIMEDIA $\mathrm{X}$-PERT). Amplifications was performed in $25 \mu \mathrm{l}$ reactions of PCR buffer in replicates and PCR reactions consists of an initial denaturation at $94^{\circ} \mathrm{C}$ for 3 minutes, for annealing 25 cycles at $94^{\circ} \mathrm{C}$ for 30 seconds, $55^{\circ} \mathrm{C}$ for 30 seconds, $72^{\circ} \mathrm{C}$ for 1 minute and final extension at $72^{\circ} \mathrm{C}$ for 10 minutes. Amplification products was electrophoresing in $0.8 \%$ agarose gel, stained with ethidium bromide and amplicons will be observed under UV light. The final PCR product was subjected to DNA sequencing. The DNA sequence was used in NCBI (National Centre for Biotechnology Information) and search tool BLAST (Basic Local Alignment Search Tool) for bioinformatics analysis, to look homologous nucleotide sequences. Based on the information, genus and species status was assigned.

\section{RESULTS}

\section{Collection and Morphological Characters}

Four samples of wild mushrooms were collected and maintenance of pure cultures was done aseptically. The microscopic features were studied under microscope by using Congo red stain. Clamp connections and chlamydospores was observed (Fig 1).
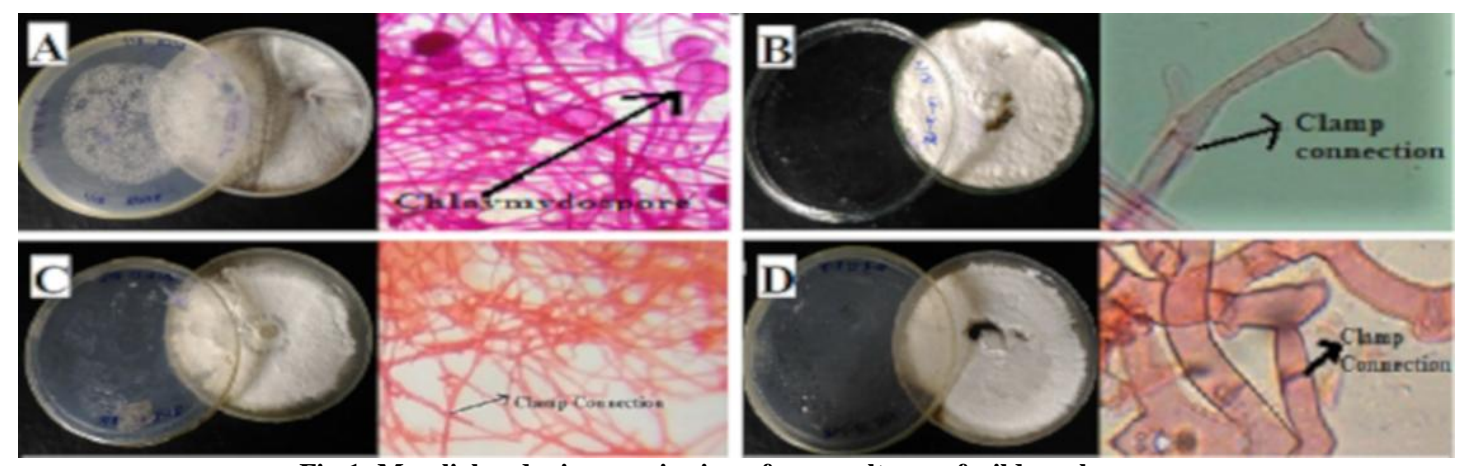

Fig-1: Mycelial and microscopic view of pure cultures of wild mushrooms.

A) Trametes versicolor, B) Daedaleopsis confragosa, C) Schizophyllum commune and D) Tyromyces chioneus

\section{Antimicrobial activity for screening}

All the methanol extract of cultures was found to be active against all the five pathogenic microorganisms. Among all the cultures, T. versicolor shows maximum activity $(29.75 \pm 0.25)$ against $K$. pneumonia, against E. coli, T. chioneus shows maximum activity (27.80 \pm 0.20$), \quad$ against Staphylococcus aureus, S. communae shows maximum

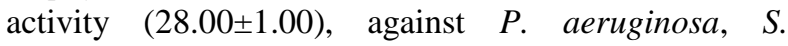
communae shows maximum activity $(26.75 \pm 0.25)$, and against $C$. albicans, $T$. chioneus shows maximum activity $(27.75 \pm 0.25)$. The results of methanol, hot water and hexane extract of different species were shown below in (Table 1 and Fig 2).

Table-1: Antimicrobial activity of Methanol (M), Hot Water (HW) and Hexane (H) extracts of different wild mushrooms culture against different pathogenic microorganisms

\begin{tabular}{|c|c|c|c|c|c|c|c|c|c|c|c|c|c|c|c|c|}
\hline \multirow{3}{*}{\begin{tabular}{l}
$n$ \\
\hdashline \\
$Z$ \\
0
\end{tabular}} & \multirow[t]{3}{*}{ Isolates } & \multicolumn{15}{|c|}{$\begin{array}{l}\text { Test micro-organisms and concentration of Methanol, Hot water and Hexane Extract } \\
\text { used }(100 \mathrm{mg} / \mathrm{ml}) \text { Zone inhibition diameter }(\mathrm{mm})\end{array}$} \\
\hline & & \multicolumn{3}{|c|}{$\begin{array}{l}\text { Klebsiella } \\
\text { pneumoniae }\end{array}$} & \multicolumn{3}{|c|}{ Escherichia coli } & \multicolumn{3}{|c|}{$\begin{array}{l}\text { Staphylococcus } \\
\text { aureus }\end{array}$} & \multicolumn{3}{|c|}{$\begin{array}{l}\text { Pseudomonas } \\
\text { aeruginosa }\end{array}$} & \multicolumn{3}{|c|}{ Candida sp. } \\
\hline & & M & HW & $\mathbf{H}$ & M & HW & H & $\mathbf{M}$ & HW & $\mathbf{H}$ & $\mathbf{M}$ & HW & $\mathbf{H}$ & $\mathbf{M}$ & HW & H \\
\hline 1 & Trametes sp. & 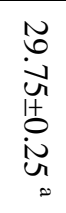 & 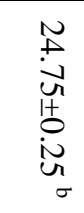 & 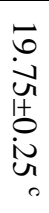 & $\begin{array}{l}\text { N } \\
\text { un } \\
\text { o } \\
\text { I } \\
\text { un } \\
\text { un } \\
\sigma\end{array}$ & $\begin{array}{l}N \\
N \\
\text { in } \\
\text { I } \\
0 \\
\text { in } \\
0 \\
0\end{array}$ & 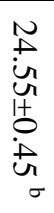 & 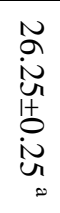 & 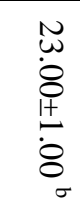 & $\begin{array}{l}\vec{\infty} \\
\dot{y} \\
\dot{0} \\
0 \\
0 \\
0 \\
0 \\
0\end{array}$ & 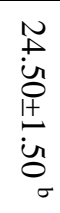 & 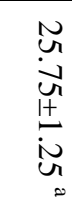 & 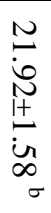 & $\begin{array}{l}\omega \\
\stackrel{N}{8} \\
\stackrel{+}{8} \\
\stackrel{+}{8} \\
0 \\
\sigma\end{array}$ & $\begin{array}{l}N \\
N \\
\dot{\omega} \\
\stackrel{1}{+} \\
0 \\
\dot{\omega} \\
0 \\
\sigma\end{array}$ & 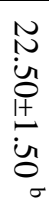 \\
\hline
\end{tabular}




\begin{tabular}{|c|c|c|c|c|c|c|c|c|c|c|c|c|c|c|c|c|}
\hline 2 & $\begin{array}{l}\text { Daedaleopsis } \\
\text { sp. }\end{array}$ & 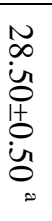 & $\begin{array}{l}\tilde{\alpha} \\
\infty \\
\infty \\
u \\
\dot{0} \\
\dot{0} \\
u \\
\infty\end{array}$ & 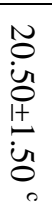 & $\begin{array}{l}\text { N } \\
\dot{8} \\
\stackrel{+}{+} \\
\stackrel{+}{8} \\
\stackrel{8}{8}\end{array}$ & $\begin{array}{l}\text { N } \\
\dot{8} \\
\stackrel{1}{+} \\
\dot{8} \\
\dot{8}\end{array}$ & 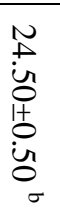 & 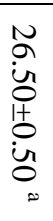 & 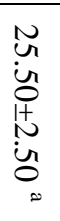 & $\begin{array}{l}\vec{\infty} \\
\dot{y} \\
\dot{\partial} \\
\dot{y} \\
\dot{y} \\
\dot{0} \\
0\end{array}$ & 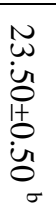 & 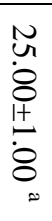 & $\begin{array}{l}\stackrel{N}{N} \\
\stackrel{8}{8} \\
\text { I } \\
\stackrel{1}{8} \\
\dot{8}\end{array}$ & 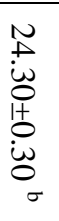 & 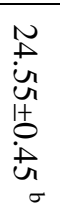 & 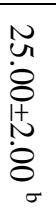 \\
\hline 3 & $\begin{array}{l}\text { Schizophyllum } \\
\text { sp. }\end{array}$ & $\begin{array}{l}\text { N } \\
\dot{8} \\
\stackrel{1}{+} \\
\dot{8}\end{array}$ & 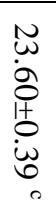 & 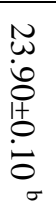 & 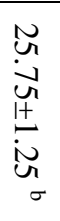 & 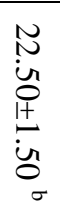 & 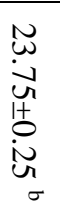 & 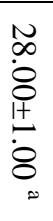 & $\begin{array}{l}\vec{b} \\
\dot{0} \\
\dot{0} \\
\dot{0} \\
\dot{8} \\
0 \\
0\end{array}$ & $\begin{array}{l}\tilde{u}_{0} \\
\dot{8} \\
\dot{1} \\
\dot{8} \\
\sigma\end{array}$ & 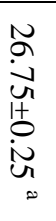 & 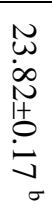 & $\begin{array}{l}\stackrel{N}{+} \\
\dot{8} \\
\stackrel{1}{+} \\
\dot{8} \\
\sigma\end{array}$ & 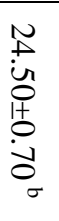 & 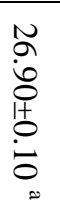 & 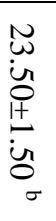 \\
\hline 4 & Tyromyces sp. & 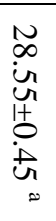 & 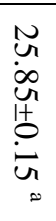 & $\begin{array}{l}\stackrel{N}{N} \\
\dot{8} \\
\stackrel{1}{+} \\
\dot{8} \\
0\end{array}$ & $\begin{array}{l}\text { N } \\
\text { o } \\
0 \\
0 \\
\dot{1} \\
\dot{0} \\
0\end{array}$ & 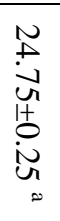 & 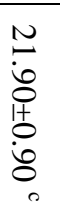 & 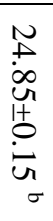 & 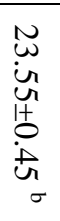 & 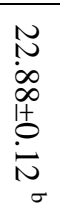 & 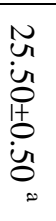 & 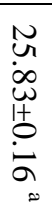 & 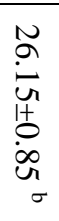 & 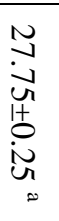 & 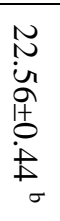 & 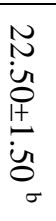 \\
\hline 5 & $\begin{array}{l}\text { Ciprofloxacin/ } \\
\text { Flucanozole } \\
\text { (Control) }\end{array}$ & 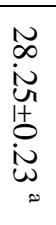 & 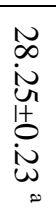 & 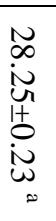 & 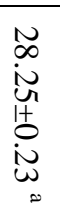 & 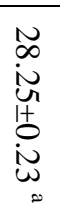 & 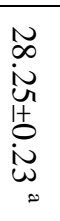 & 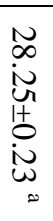 & 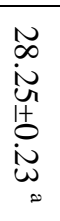 & 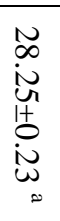 & 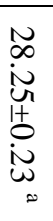 & 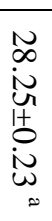 & 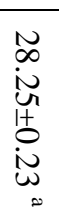 & 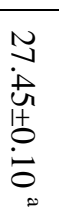 & 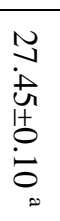 & $\begin{array}{l}\text { N } \\
\text { D. } \\
\text { H } \\
1 \\
0 \\
0 \\
0\end{array}$ \\
\hline
\end{tabular}
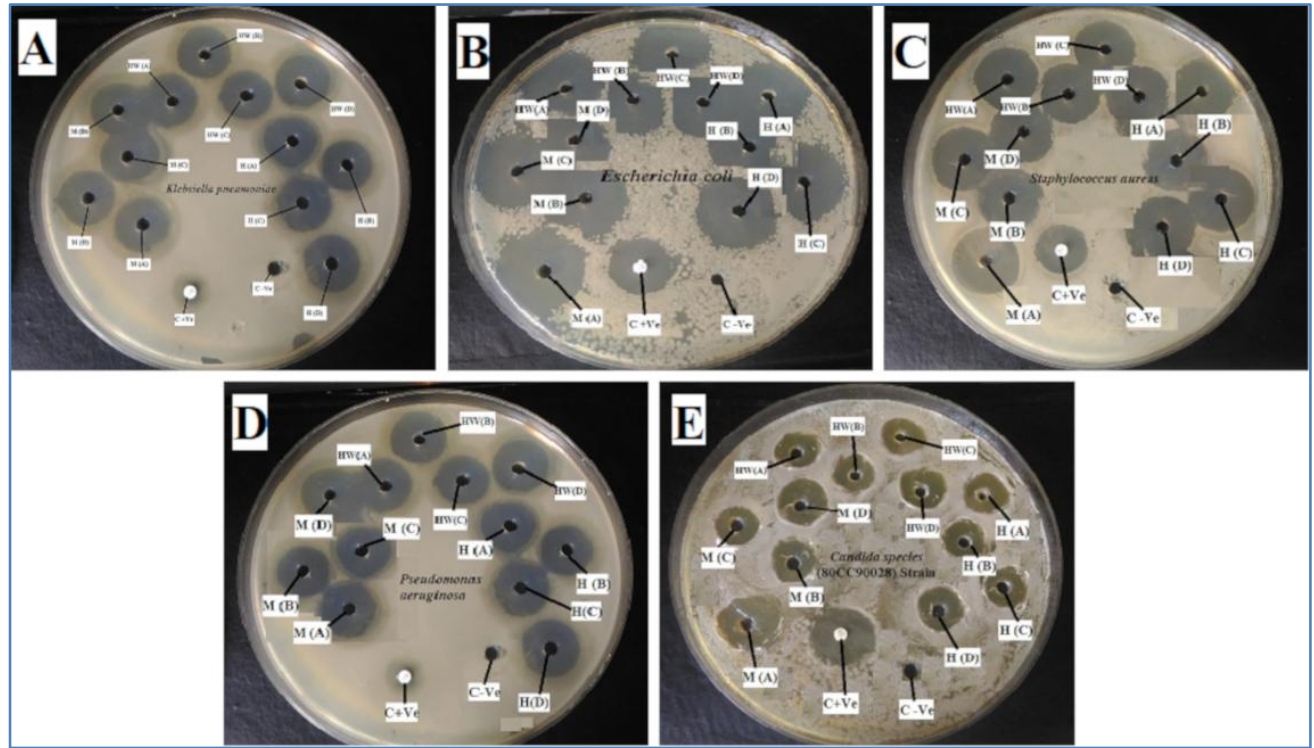

Fig-2: Zone of inhibition of Methanol, Hot Water and Hexane extracts of four wild mushroom cultures against Pathogenic microorganisms.

A) Klebsiella pneumoniae, B) Escherichia coli, C) Staphylococcus aureus, D) Pseudomonas aeruginosa and Candida sp. M (A) Activity of Methanol extract of Trametes sp., M (B) Daedaleopsis sp., M (C) Schizophyllum sp. and M (D) Tyromyces sp., HW (A) Activity of Hot water extract of Trametes sp., HW (B) Daedaleopsis sp., HW (C) Schizophyllum sp., and HW (D) Tyromyces sp., H (A) Activity of Hexane extract of Trametes sp., H (B) Daedaleopsis sp., H (C) Schizophyllum sp., and H (D) Tyromyces sp. C + ve is positive control Ciprofloxacin and $\mathrm{C}-\mathrm{ve}$ is negative control DMSO.

Minimal inhibitory concentration of methanol, hot water and hexane extract

According, to results all four-methanol extract of mushroom cultures exhibit a good antimicrobial spectrum activity compared to hot water extract and hexane extract. $S$. communae of methanol extract is best to potentiate the antibacterial activity of $S$. aureus and 
P. aeruginosa with MIC $0.39 \mathrm{mg} / \mathrm{ml}$. against fungal strain of $C$. albicans extract of $S$. communae showed good activity with MIC $0.39 \mathrm{mg} / \mathrm{ml}$. Extract of $S$. communae showed high antibacterial potential against
$K$. pneumoniae and E. coli with MIC $1.56 \mathrm{mg} / \mathrm{ml}$. The results of minimal inhibitory concentration of methanol extract shown in below (Table 2).

Table-2: Minimal inhibitory concentration of Methanol (M), Hot Water (HW) and Hexane (H) extracts of different wild mushrooms culture against different pathogenic microorganisms

\begin{tabular}{|c|c|c|c|c|c|c|c|c|c|c|c|c|c|c|c|c|}
\hline \multirow{3}{*}{$\begin{array}{l}\text { Sr. } \\
\text { No }\end{array}$} & \multirow[t]{3}{*}{ Isolates } & \multicolumn{15}{|c|}{ Minimal inhibitory concentration of methanol extracts (mg/ml) } \\
\hline & & \multicolumn{3}{|c|}{$\begin{array}{l}\text { Klebsiella } \\
\text { pneumoniae }\end{array}$} & \multicolumn{2}{|c|}{$\begin{array}{l}\text { Escherichia } \\
\text { coli }\end{array}$} & \multicolumn{4}{|c|}{ Staphylococcus aureus } & \multicolumn{3}{|c|}{$\begin{array}{l}\text { Pseudomonas } \\
\text { aeruginosa }\end{array}$} & \multicolumn{3}{|c|}{ Candida sp. } \\
\hline & & M & HW & $\mathbf{H}$ & M & HW & $\mathbf{H}$ & M & HW & $\mathbf{H}$ & M & HW & $\mathbf{H}$ & $\mathbf{M}$ & HW & $\mathbf{H}$ \\
\hline 1 & Trametes sp. & 6.25 & 1.56 & 3.12 & 12.5 & 1.56 & 3.12 & 3.12 & 0.39 & 12.5 & 3.12 & 0.39 & 6.25 & 1.56 & 0.39 & 6.25 \\
\hline 2 & Daedaleopsis sp. & 12.5 & 12.5 & 6.25 & 25 & 25 & 1.56 & 12.5 & 12.5 & 1.56 & 6.25 & 6.25 & 1.56 & 3.12 & 3.12 & 0.78 \\
\hline 3 & $\begin{array}{l}\text { Schizophyllum } \\
\text { sp. }\end{array}$ & 1.56 & 1.56 & 3.12 & 1.56 & 1.56 & 25 & 0.39 & 0.39 & 25 & 0.39 & 0.39 & 25 & 0.39 & 0.39 & 12.5 \\
\hline 4 & Tyromyces sp. & 6.25 & 1.56 & 12.5 & 25 & 0.39 & 25 & 1.56 & 0.78 & 50 & 1.56 & 3.12 & 12.5 & 0.78 & 0.39 & 25 \\
\hline
\end{tabular}

\section{Qualitative analysis of bioactive compounds}

The preliminary phytoconstituents analysis of all isolates revealed that the methanol, hot water and hexane extracts contain Alkaloids, Tannins, Terpeonoids, Carbohydrates, Phenols, Flavonoids, Glycosides and Saponins as shown in (Table 3).

Table-3: Qualitative analysis of methanol, hot water and hexane extracts of wild mushroom cultures

\begin{tabular}{|c|c|c|c|c|c|c|c|c|c|c|c|c|c|}
\hline \multicolumn{14}{|c|}{ Qualitative analysis of Methanol, Hot Water and Hexane extracts } \\
\hline \multirow[t]{2}{*}{ Sr. No. } & \multirow[t]{2}{*}{ Phytochemicals } & \multicolumn{3}{|c|}{ Trametes sp. } & \multicolumn{3}{|c|}{ Daedaleopsis sp. } & \multicolumn{3}{|c|}{ Schizophyllum sp. } & \multicolumn{3}{|c|}{ Tyromyces sp. } \\
\hline & & $\mathrm{M}$ & HW & $\mathrm{H}$ & $\mathrm{M}$ & HW & $\mathrm{H}$ & $\mathrm{M}$ & HW & $\mathrm{H}$ & $\mathrm{M}$ & HW & $\mathrm{H}$ \\
\hline 1 & Alkaloids & + & - & - & + & - & - & + & + & - & + & + & + \\
\hline 2 & Carbohydrates & + & - & + & + & + & - & + & + & + & + & + & - \\
\hline 3 & Flavonoids & + & + & + & + & + & + & + & + & + & + & + & + \\
\hline 4 & Terpeonoids & + & + & + & + & + & + & + & + & + & + & + & + \\
\hline 5 & Phenols & + & + & + & + & + & + & + & + & - & - & + & + \\
\hline 6 & Tannins & + & - & - & + & + & + & + & + & - & + & + & + \\
\hline 7 & Glycosides & + & + & + & + & - & - & + & + & + & + & + & - \\
\hline 8 & Saponins & + & + & - & + & + & - & + & + & - & - & - & - \\
\hline
\end{tabular}

Quantitative analysis of phytochemical compounds

Phenolic compounds are known to be powerful chain-breaking antioxidants and they possess scavenging ability due to their hydroxyl groups. There must be phenolic compounds which contribute directly to the anti-oxidative action.

In present study, that is for phenols hot water extract is the best compare to methanol and hexane extracts. The phenol content in hot water extract of $T$. versicolor was $(11.13 \pm 0.081 \mu \mathrm{g} / \mathrm{ml}), D$. confragosa was $(8.27 \pm 0.046 \mu \mathrm{g} / \mathrm{ml}), S$. communae was $(9.52 \pm 0.210$ $\mu \mathrm{g} / \mathrm{ml})$ and $T$. chioneus was $(5.53 \pm 0.105 \mu \mathrm{g} / \mathrm{ml})$ observed.

For flavonoids methanol extract is having more efficiency compare to hot water and hexane extracts. The flavonoids content in methanol extract of T. versicolor was $(10.04 \pm 0.057 \mu \mathrm{g} / \mathrm{ml}), D$. confragosa was $(10.26 \pm 0.073 \mu \mathrm{g} / \mathrm{ml}), \quad S$. communae was $(12.58 \pm 0.138 \mu \mathrm{g} / \mathrm{ml})$ and $T$. chioneus was $(10.76 \pm 0.100$ $\mu \mathrm{g} / \mathrm{ml})$.

For ascorbic acid content in these mushrooms hot water extract shows best results compare to methanol and hexane extract. The ascorbic acid content in hot water extract of $T$. versicolor was $(9.62 \pm 0.086$ $\mu \mathrm{g} / \mathrm{ml})$, D. confragosa was $(7.22 \pm 0.104 \mu \mathrm{g} / \mathrm{ml}), S$. communae was $(7.48 \pm 0.165 \mu \mathrm{g} / \mathrm{ml})$ and $T$. chioneus was $(6.66 \pm 0.047 \mu \mathrm{g} / \mathrm{ml})$.

For $\beta$-carotene methanol extract shows efficiency compare to hot water extract and hexane extract. The $\beta$-carotene content in methanol extract of $T$. versicolor was $(2.41 \pm 0.305 \mu \mathrm{g} / \mathrm{ml}), D$. confragosa was $(3.10 \pm 0.056 \mu \mathrm{g} / \mathrm{ml}), S$. communae was $(2.27 \pm 0.026$ $\mu \mathrm{g} / \mathrm{ml})$ and $T$. chioneus was $(3.54 \pm 0.010 \mu \mathrm{g} / \mathrm{ml})$.

For lycopene methanol extract is best compare to hot water extract and hexane extract. The lycopene content in methanol extract of $T$. versicolor was $(2.02 \pm 0.015 \mu \mathrm{g} / \mathrm{ml})$, D. confragosa was $(1.94 \pm 0.017$ $\mu \mathrm{g} / \mathrm{ml}), S$. communae was $(2.13 \pm 0.018 \mu \mathrm{g} / \mathrm{ml})$ and $T$. chioneus was $(0.18 \pm 0.003 \mu \mathrm{g} / \mathrm{ml})$.

Totals phenols, flavonoids, ascorbic acid, $\beta$ carotene and lycopene were the major naturally occurring antioxidant components estimated in this study. The higher amounts of these components in these three extracts (methanol, hot water and hexane) might explain its effectiveness in antioxidant properties.

\section{DPPH Radical Scavenging activity}

The DPPH assay is based on the capability of an antioxidant to donate hydrogen radical or an electron to DPPH radical, which is stable free radical with deep 
violet colour. As shown in (Table 4), the scavenging ability of the methanol extract was highest for $S$. communae ranges from $11.27 \pm 0.14$ to $76.59 \pm 0.08$ followed by $T$. chioneus ranges from $38.66 \pm 0.19$ to $75.43 \pm 0.11, D$. confragosa ranges from $25.43 \pm 0.05$ to
$73.81 \pm 0.08, T$. versicolor $18.30 \pm 0.03$ to $65.97 \pm 0.32$, respectively. Ascorbic acid was taken as standard which showed excellent scavenging activity of $83.57 \pm 0.01 \%$ as shown in (Table 4).

Table-4: Scavenging ability of Methanol extract from different isolates on 2,2-diphenyl-1-picrylhydrazyl radicals

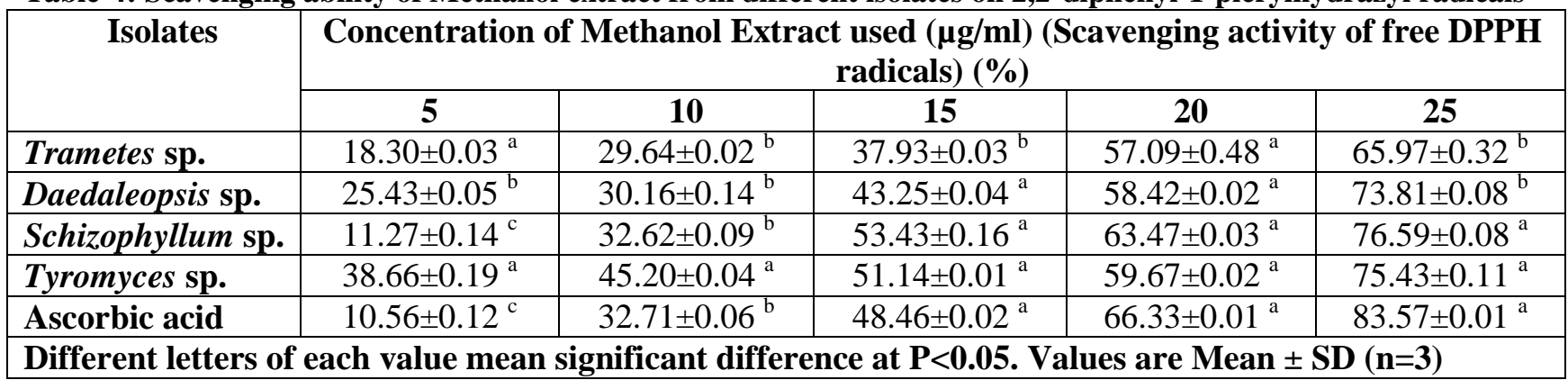

According to recent research, polar solvents are the best for the extraction of antioxidants. The $\mathrm{IC}_{\mathbf{5 0}}$ value was calculated to determine the concentration of the sample required to inhibit $50 \%$ of radical. Therefore, the extracts which possess $\mathrm{IC}_{\mathbf{5 0}}$ values ranging from 50 to $100 \mathrm{mg} / \mathrm{mL}$ is considered to exhibit intermediate antioxidant activity. Meanwhile, extracts with $\mathrm{IC}_{\mathbf{5 0}}$ value ranging between 10 to $50 \mathrm{mg} / \mathrm{mL}$ is considered to possess strong antioxidant activity [21]. The $\mathrm{IC}_{\mathbf{5 0}}$ value of methanol extract of Trametes species is $4.9 \mathrm{mg} / \mathrm{ml}$, D. confragosa is $4.8 \mathrm{mg} / \mathrm{ml}, S$. communae is $4.9 \mathrm{mg} / \mathrm{ml}$ and $T$. chioneus is $4.4 \mathrm{mg} / \mathrm{ml}$.

\section{Molecular identification of wild mushrooms}

DNA is successfully was extracted from the cultures of mycelium from wild mushrooms by liquid nitrogen. After centrifugation the genomic DNA is extracted and PCR reactions were carried out successfully by using universal primers (ITS1 forward primer and ITS4 reverse primer) were used for the amplification of the ITS regions of the wild mushrooms. The PCR amplification products showed that $T$. versicolor showed about 723 bp amplified band, D. confragosa showed about $577 \mathrm{bp}$ amplified band, while $S$. communae gave about 562 bp amplified band and $T$. chioneus showed about 895 bp amplified bands respectively (Fig 3).

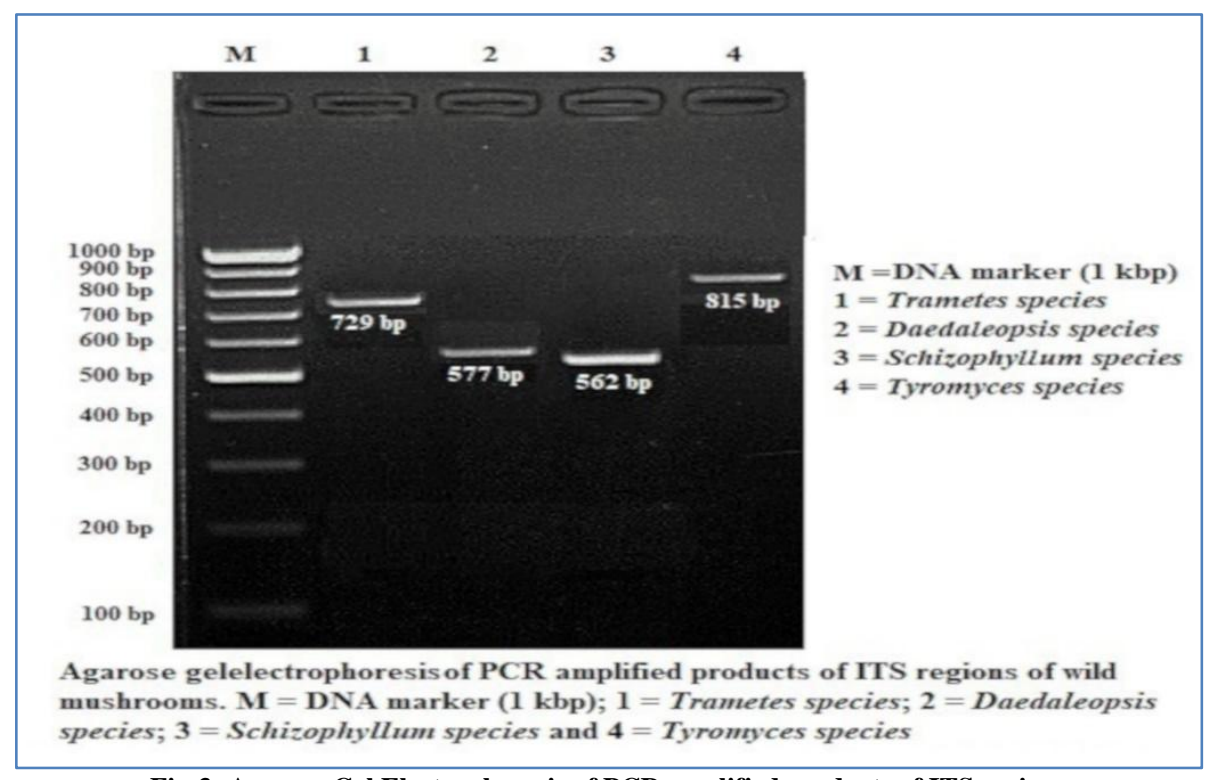

Fig-3: Agarose Gel Electrophoresis of PCR amplified products of ITS regions

The DNA marker which is used is $1 \mathrm{kbp}$. The PCR products were gel purified, run in $1 \%$ agarose gel, and processed for nucleotide sequencing. The nucleotide sequences of four samples were obtained and then analysed for Basic Local Alignment Search Tool (BLAST).
According to BLAST summary of the samples, they were closely resembled to these species. Identification was based on \% highest coverage and followed by the Accession no. were presented. The mushrooms may be identified as follows: 1/18Trametes versicolor (100\% AY138396.1), 2/18- 
Daedaleopsis confragosa (99\% KR108001.1), 3/18Schizophyllum commune (99\% AF062633.1), and 4/18Tyromyces chioneus (99\% KX066001.1). The aligned nucleotide sequence of samples was submitted to NCBI and nucleotide sequences of four samples is provided with gene bank accession number MK249878 (Trametes versicolor), MK239266 (Daedaleopsis confragosa), MK212358 (Schizophyllum commune) and MK239265 (Tyromyces chioneus).

\section{Phylogenetic analysis of wild mushrooms}

Construction of Phylogenetic Tree of mushroom samples by using NCBI (National Centre for Biotechnology Information and MEGA (Molecular Evolutionary Genetics Analysis) Software shown in (Fig 4)

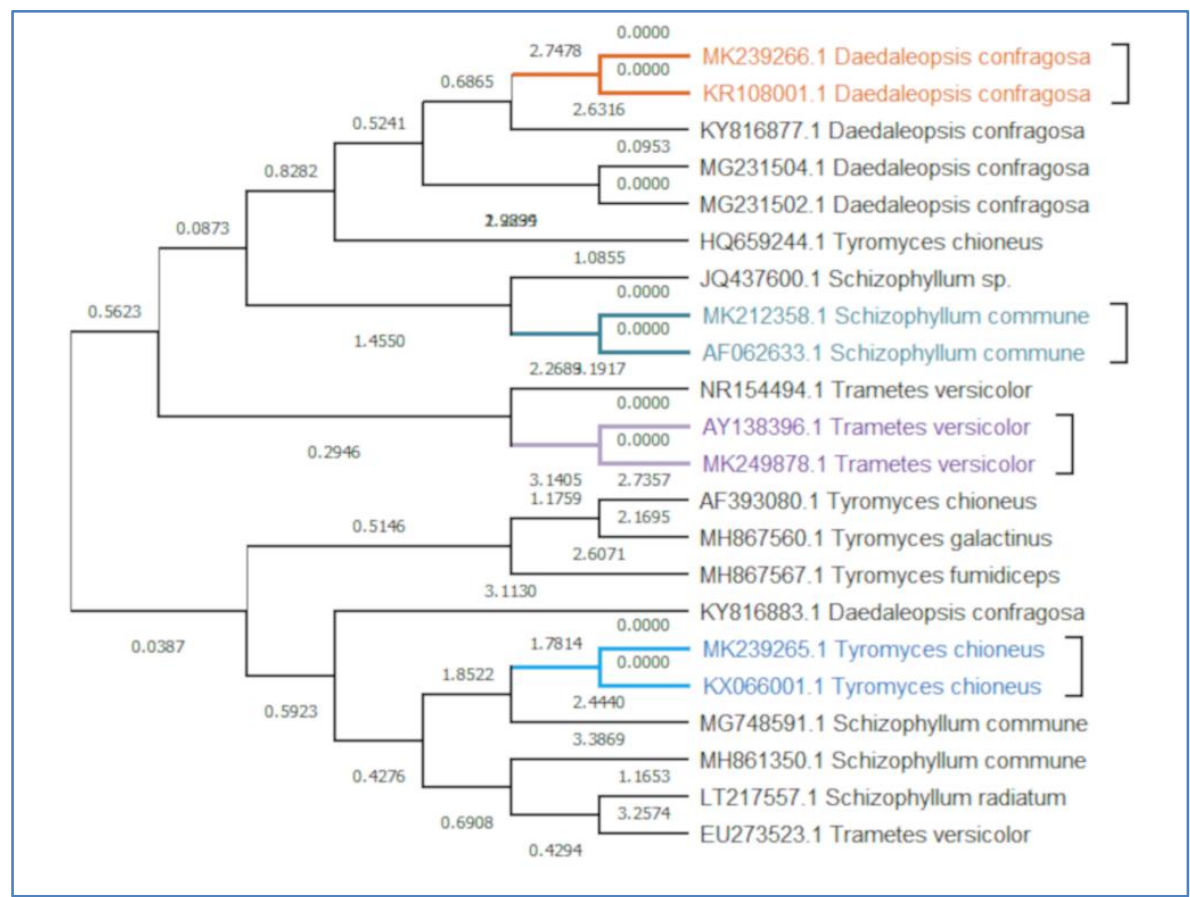

Fig-4: Phylogenetic analysis of four samples (Daedaleopsis confragosa, Schizophyllum commune, Trametes versicolor and Tyromyces chioneus)

The evolutionary history was inferred using the Neighbour-Joining method. The optimal tree with the sum of branch length $=52.19427294$ is shown. The tree is drawn to scale, with branch lengths in the same units as those of the evolutionary distances used to infer the phylogenetic tree. The evolutionary distances were computed using the Maximum Composite Likelihood method and are in the units of the number of base substitutions per site. This analysis involved 22 nucleotide sequences. All ambiguous positions were removed for each sequence pair (pairwise deletion option). There were a total of 1463 positions in the final dataset. Evolutionary analyses were conducted in MEGA X.

\section{DISCUSSIONS}

Methanol extract of $T$. elegans produced the highest anticandidal activity with an inhibition zone of $30.00 \mathrm{~mm}$ against isolate $C$. albicans [22]. This finding was in the agreement of [23] that the antibacterial activity of polypores and gilled mushrooms was found to be more pronounced than antifungal activity [23]. As in most cases, it appears that the fungal strains are more resistant to antimicrobial compounds than bacterial strains $[24,25]$. The filamentous fungus, $S$. commune produced metabolites that possessed antifungal activity
[26]. When an odd electron becomes paired in the presence of free radical scavenger of antioxidant agent, DPPH radicals get reduced to corresponding hydrazine, DPPH-H form [27]. Due to quenching of its free radicals by antioxidants present in the medium the deep purple colour disappears, i.e., by electron donation or by providing hydrogen atom via free radical attack on DPPH molecule and convert them to colourless bleached product known as 2,2 diphenyl-1-hydrazine. This results in decrease in the absorption at $517 \mathrm{~nm}$, hence, more rapidly the decrease in absorbance more potent the antioxidant activity of the extract [9]. The lower the $\mathrm{IC}_{\mathbf{5 0}}$ value, the higher the antioxidant activity of samples [28].

\section{CONCLUSION}

From the above, study it is concluded that all four mushrooms $T$. versicolor, $D$. confragosa, $S$. communae and $T$. chioneus have potent antimicrobial and antioxidant properties which can be exploited for its medicinal purpose at industrial and pharmaceutical level. The nucleotide sequence of samples was submitted to NCBI and nucleotide sequences of four samples is provided with gene bank accession number MK249878 (Trametes versicolor), MK239266 (Daedaleopsis confragosa), MK212358 (Schizophyllum 
commune) and MK239265 (Tyromyces chioneus). All species of mushroom has shown good antioxidant activity. The antioxidant potential of the methanolic extracts of the mushroom samples in this study recorded higher values. According to the results, this indicates that the mushrooms have high antioxidant properties and rationalizes further investigation in the potential discovery of new natural bioactive principles from these mushrooms. It also reveals a novel potential to fight against diseases. Mushrooms are rich source of natural antibiotics, in these, the cell wall glucans are well known for their immunomodulatory properties and many of the externalized secondary metabolites. According to research, flavonoids and phenolic compounds contribute largely to antioxidant affect.

\section{ACKNOWLEDGEMENT}

The author thanks Shoolini University of Biotechnology and Management Sciences, Solan (Himachal Pradesh), IMTECH (Chandigarh), Eurofins (Bangalore) and Family members for assisting to complete my research successfully.

\section{REFERENCES}

1. Karaman, M., Novakovic, M., \& Matavuly, M. (2012). Fundamental fungal strategies in restoration of natural environment. Fungi: Types, environmental impact and role in disease. New York: Nova Science Publishers Inc.

2. Dickinson, C. H., \& Lucas, J. A. (Eds.). (1982). VNR color dictionary of mushrooms. Van Nostrand Reinhold.

3. Crous, P. W., Rong, I. H., Wood, A., Lee, S., Glen, H., Botha, W., ... \& Hawksworth, D. L. (2006). How many species of fungi are there at the tip of Africa?. Studies in mycology, 55, 13-33.

4. Cai, Y. F., Chen, S. H., Dent, J. B., Dutta, S., \& Saridakis, E. N. (2011). Matter bounce cosmology with the $\mathrm{f}(\mathrm{T})$ gravity. Classical and Quantum Gravity, 28(21), 215011.

5. Chang, Y. S., \& Lee, S. S. (2004). Utilisation of macrofungi species in Malaysia. Fungal Diversity, 15, 15-22.

6. Gao, Y., Dai, X., Chen, G., Ye, J., \& Zhou, S. (2003). A randomized, placebo-controlled, multicenter study of Ganoderma lucidum (W. Curt.: Fr.) Lloyd (Aphyllophoromycetideae) polysaccharides (Ganopoly®) in patients with advanced lung cancer. International Journal of Medicinal Mushrooms, 5(4).

7. Alves, M. J., Ferreira, I. C., Dias, J., Teixeira, V., Martins, A., \& Pintado, M. (2012). A review on antimicrobial activity of mushroom (Basidiomycetes) extracts and isolated compounds. Planta medica, 78(16), 1707-1718.

8. Wasser, S. P., \& Weis, A. L. (1999). Medicinal properties of substances occurring in higher basidiomycetes mushrooms: current perspectives. International Journal of medicinal mushrooms, 1(1).
9. Bains, A. A. R. T. I., Tripathi, A., \& SHARMA, A. (2015). Antibacterial and antioxidant properties of wild mushrooms collected from Himachal Pradesh. International Journal of Biology, Pharmacy and Allied Sciences, 4(10), 6161-6170.

10. Bains, A., \& Tripathi, A. (2016). Antibacterial activity and phytochemical screening of wild edible mushroom pleurotus ostreatuscollected from himachal pradesh. International Journal, 4(4), 467-474.

11. Moshi, M. J., Mbwambo, Z. H., Kapingu, M. C., Mhozya, V. H., \& Marwa, C. (2006). Antimicrobial and brine shrimp lethality of extracts of Terminalia mollis Laws. African Journal of Traditional, Complementary and Alternative Medicines, 3(3), 59-69.

12. Wiegand, I., Hilpert, K., \& Hancock, R. E. (2008). Agar and broth dilution methods to determine the minimal inhibitory concentration (MIC) of antimicrobial substances. Nature protocols, 3(2), 163.

13. Sofowora, A. (1996). Medicinal plants and traditional medicine in Africa. Karthala.

14. Subbulakshmi, M., \& Kannan, M. (2016). Cultivation and phytochemical analysis of wild mushrooms Daldinia concentrica and Pheolus schweinitzii from Tamilnadu, India. European Journal of Experimental Biology, 6(3), 46-54.

15. Brunner, J. H. (1984). Direct spectrophotometric determination of saponin. Analytical Chemistry, 34(396), 1314-1326.

16. Singleton, V. L., Orthofer, R., \& LamuelaRaventós, R. M. (1999). [14] Analysis of total phenols and other oxidation substrates and antioxidants by means of folin-ciocalteu reagent. In Methods in enzymology (Vol. 299, pp. 152178). Academic press.

17. Zhishen, J., Mengcheng, T., \& Jianming, W. (1999). The determination of flavonoid contents in mulberry and their scavenging effects on superoxide radicals. Food chemistry, 64(4), 555559.

18. Klein, B. P., \& Perry, A. K. (1982). Ascorbic acid and vitamin A activity in selected vegetables from different geographical areas of the United States. Journal of Food Science, 47(3), 941-945.

19. Nagata, M., \& Yamashita, I. (1992). Simple method for simultaneous determination of chlorophyll and carotenoids in tomato fruit. Nippon Shokuhin Kogyo Gakkaishi, 39(10), 925-928.

20. Feresin, G. E., Tapia, A., Angel, G. R., Delporte, C., Erazo, N. B., \& Schmeda- Hirschmann, G. (2002). Free radical scavengers, antiinflammatory and analgesic activity of Acaena magellanica. Journal of pharmacy and pharmacology, 54(6), 835-844.

21. Phongpaichit, S., Nikom, J., Rungjindamai, N., Sakayaroj, J., Hutadilok-Towatana, N., 
Rukachaisirikul, V., \& Kirtikara, K. (2007). Biological activities of extracts from endophytic fungi isolated from Garcinia plants. FEMS Immunology \& Medical Microbiology, 51(3), 517-525.

22. Harborne, J.B. (1973). Phytochemical Methods. Chapman and Hall Ltd., London pp. 49-188.

23. Suay, I., Arenal, F., Asensio, F. J., Basilio, A., Cabello, M. A., Díez, M. T., ... \& Peláez, F. (2000). Screening of basidiomycetes for antimicrobial activities. Antonie van Leeuwenhoek, 78(2), 129-140.

24. Nishizawa, K., Amano, Y., Nozaki, K., Kanda, T., Hosokawa, N., \& Shiroishi, M. (2003). Some characteristics of three groups in Flammulina velutipes classified by analysis of esterase isozymes. Mycoscience, 44(1), 19-23.

25. Papadopoulou, C., Soulti, K., \& Roussis, I. G. (2005). Potential antimicrobial activity of red and white wine phenolic extracts against strains of
Staphylococcus aureus, Escherichia coli and Candida albicans. Food Technology and Biotechnology, 43(1), 41-46.

26. Teoh, Y. P., Don, M. M., \& Ujang, S. (2012). Nutrient improvement using statistical optimization for growth of Schizophyllum commune, and its antifungal activity against wood degrading fungi of rubberwood. Biotechnology progress, 28(1), 232241.

27. Paixao, N., Perestrelo, R., Marques, J. C., \& Câmara, J. S. (2007). Relationship between antioxidant capacity and total phenolic content of red, rosé and white wines. Food Chemistry, 105(1), 204-214.

28. Li, E., Tian, R., Liu, S., Chen, X., Guo, L., \& Che, Y. (2008). Pestalotheols A- D, bioactive metabolites from the plant endophytic fungus Pestalotiopsis theae. Journal of Natural Products, 71(4), 664-668. 